\section{Pelaksanaan Pelatihan Strategi Kepemimpinan Bagi Pegawai BPR Mitra Daya Mandiri Bogor}

\author{
Annaria Magdalena Marpaung dan Bintang Sahala Marpaung \\ Program Studi Manajemen, Institut Bisnis dan Informatika Kesatuan \\ Bogor, Indonesia
}

E-Mail: annaria@ibik.ac.id
Submitted: MEI 2020

Accepted: JUNI 2020

\begin{abstract}
ABSTRAK
Kegiatan Pengabdian kepada Masyarakat ini bertujuan untuk meningkatkan pengetahuan dan pemahaman para pegawai BPR Mitra Daya Mandiri di Kota Bogor yang terkait dengan pengetahuan strategi kepemimpinan. Minimnya pengetahuan tentang strategi kepemimpinan bagi para calon pemimpin di BPR Mitra Daya Mandiri, menimbulkan kesulitan dalam mengembangkan usaha BPR karena tidak mengetahui dengan strategi kepemimpinan yang akan dijalankan oleh seluruh karyawan yang terlibat dalam kegiatan di BPR Mitra Daya Mandiri, tentu hal ini juga berdampak kepada terbatasnya perkembangan usaha di BPR Mitra Daya Mandiri. Untuk dapat membuat mengarahkan seluruh karyawan yang terlibat dalam aktivitas perusahaan, sebagai seorang pemimpin di BPR Mitra Daya harus memiliki strategi dalam menjalankan kepemimpinannya. Karena itu, pimpinan BPR Mitra Daya perlu memberikan pengarahan kepada seluruh karyawannya terkait dengan strategi yang akan dijalankan dalam pencapaian tujuan perusahaan, khususnya pencapaian tujuan di BPR Mitra Daya Mandiri. Melalui pelatihan ini diharapkan akan membuka wawasan para calon pemimpin di BPR Mitra Daya Mandiri terutama terkait dengan strategi kepemimpinan, seperti : pengertian kepemimpinan, pentingnya peran kepemimpinan, dan strategi kepemimpinan guna membantu karyawan untuk bekerja dan pencapaian tujuan organisasi. Hasil dari pelaksanaan pelatihan ini, diharapkan para calon pemimpin BPR Mitra Daya Mandiri di Kota Bogor akan mengatahui dan mempraktekan yang terkait dengan strategi kepemimpinan, guna membantu karyawannya agar bekerja dengan lebih baik, sehingga akan berdampak pada kemajuan dan perkembangan usaha BPR Mitra Daya Mandiri menjadi semakin berkembang dan semakin baik.
\end{abstract}

Kata Kunci: Strategi Kepemimpinan, Calon Pemimpin BPR Mitra Daya Mandiri

\section{PENDAHULUAN}

Analisis Situasi

Suatu oganisasi akan berhasil atau gagal sebagian besar ditentukan oleh kepemimpinan. Karena pemimpin secara umum yang bertanggung jawab atas kegagalan atau keberhasilan pelaksanaan suatu pekerjaan, bahkan pemimpinlah yang menjadi faktor utama penentu keberhasilan dari suatu pekerjaan. Secara umum seorang pemimpin harus memiliki pegetahuan yang luas akan berbagai hal. Pengetahuan tersebut bagi seorang pemimpin akan menjadi referensi dalam pengambilan keputusan. Pemimpin dapat dikatakan efektif apabila mampu menciptakan situasi yang dapat memberi inspirasi bagi para pengikutnya untuk mencapai tujuan yang lebih baik dan lebih tinggi lagi dari keadaan sekarang. Seorang pemimpin dapat dikatakan efektif apabila orang tersebut dapat membaca situasi, mengatasi permasalahan, bertanggungjawab, dan dapat mengembangkan pengikutnya. Pemimpin harus mempunyai

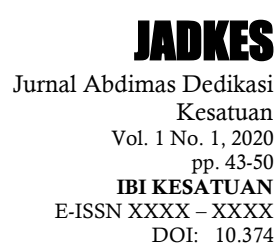

DOI: 10.374 
Kompetensi

Kepemimpinan

Karyawan

\section{4}

\section{JADKES}

Jurnal Abdimas Dedikasi

Kesatuan

Vol. 1 No. 1,2020

pp. $43-50$

IBI KESATUAN

E-ISSN XXXX - XXXX

DOI: kapabilitas, integritas dan etika yang baik serta rasa memiliki yang tinggi terhadap perusahaan atau lembaga, karena seorang pemimpin harus dapat memberikan contoh sebagai panutan orang yang dipimpinnya. Karenanya seorang pemimpin harus merumuskan strategi kepemimpinannya. Strategi kepemimpinan sangat penting dalam mendukung pertumbuhan organisasi, baik organisasi besar maupun kecil. Banyak para ahli memiliki pandangan yang berbeda tentang strategi kepemimpinan yang terbaik bagi pengembangan keseluruhan organisasi. Karena untuk dapat menjalankan organisasi agar tetap berjalan dan berkembang sangat dibutuhkan seorang pemimpin yang memiliki strategi yang dapat menghadapi tantangan global organisasi yang ada. Untuk itu organisasi membutuhkan strategi yang inovatif dari para pemimpinnya, agar organisasi dapat tetap menjalankan usahanya. Kepemimpinan yang positif, dapat membawa kepastian dan stabilitas bagi sebuah organisasi

Menurut Ki Hajar Dewantara dikutip dari Wursanto (2005: 205) syarat kepemimpinan adalah sesuai dengan azas "Hing Ngarsa Sung Tulada, Hing Madya Mangun Karsa, Tutwuri Handayani". Hingarsa (didepan), tulada (teladan, contoh), yang berarti seorang pemimpin di tengah-tengah masyarakat harus mampu memberi contoh, memberi teladan yang baik kepada para bawahan/pengikut. Hing madya (di tengah-tengah), mangun karsa (membangun semangat), yang berarti seorang pemimpin harus senantiasa ada di tengah-tengah para pengikutnya dan mampu membangkitkan semangat para bawahan. Tut wuri (dari belakang), handayani (memberikan dorongan, memberikan pengaruh), yang berarti seorang pemimpin dari belakang ia harus mampu memberikan dorongan, memberikan pengaruh yang baik kepada para bawahan.

Karakteristik kepemimpinan menurut Abdul Rahman Kadir (2001: 5) merupakan aktualisasi karakter kepemimpinan yang diharapkan bangsa dan negara, yang mampu : a. Memiliki kecerdasan, cermat dan tangguh sehingga mampu bekerja secara professional keilmuan dalam jabatannya. Hasil pekerjaanya berguna bagi dirinya, keluarga, masyarakat, bangsa dan negara. $b$. Memiliki rasa kehormatan diri (a sense of personal honour and personal dignity) dan berdisiplin pribadi, sehingga mampu dan mempunyai rasa tanggungjawab pribadi atas perilaku pribadinya. Tidak seperti keadaan saat ini, dimana para pemimpin sering tidak siap menerima pendapat dari rekan sejawatnya yang berbeda pandangan. c. Memiliki kemampuan berkomunikasi, semangat " team work", kreatif, percaya diri, inovatif dan mobilitas.

Berbeda dengan Kartini Kartono (2006: 348), yang mengatakan bentuk kepemimpinan khas yang dikehendaki saat ini adalah kepemimpinan yang berorientasi pada kekaryaan. Kepemimpinan ini mempunyai ciri-ciri sebagai berikut : a. memiliki kemahiran sosial (social skill), seperti : bertakwa kepada Tuhan Yang Maha Esa, setia dan patuh kepada Negara Kesatuan Republik Indonesia berdasarkan pancasila dan Undang-Undang Dasar 1945, berkepribadian dan berbudi pekerti luhur, bersifat kesatria, kuat mental dan moralnya, serta berkecerdasan tinggi dan tangguh, berdisiplin dan kreatif.

Disamping social skill, pemimpin juga harus memiliki keterampilan sosial lainnya, seperti : a. mampu berorganisasi, menyusun rencana, melaksanakan serta mengkoordinasikan semua kegiatan/karya, sesuai dengan program yang ada. $b$. berani bertanggung jawab atas semua tindakan dan tingkah lakunya; sanggup dengan cepat mengambil keputusan yang bijaksana. c. mampu mengelola semua bentuk karya/kerja membangun secara tepat-guna (efisien, efektif, administratif) semua tenaga manusia, sarana, material, serta waktu. dan d. sanggup berwiraswasta (Kartono,2006: 345).

Seorang pemimpin dituntut untuk memiliki karakteristik "kepemimpinan yang efektif" yang dapat memimpin untuk mencapai tujuan yang diinginkan dan membawa organisasinya ke situasi yang lebih baik dan mencapai hasil yang diinginkan. Disamping itu seorang pemimpin harus mengedepankan kepentingan organisasi daripada kepentingan pribadinya dan selalu dapat menguasai situasi bahkan dalam situasi yang terburuk sekalipun, serta mampu mengatasi berbagai permasalahan lainnya. Sebaliknya seorang pemimpin apabila dianggap tidak mampu menunjukkan karakteristik kepemimpinan yang efektif, maka organisasinya juga tidak akan dapat berjalan secara 
efektif dalam mencapai tujuan yang diinginkan, dia akan dianggap sebagai pemimpin yang tidak mampu mengendalikan institusi.

Disamping itu seorang pemimpin juga harus memiliki keterampilan personal antara lain kemampuan untuk memahami perilaku individu dan perilaku kelompok, karena kedua perilaku ini memberi kontribusi dalam membentuk dinamika organisasi. Selain itu pemimpin juga harus memiliki kapabilitas untuk memodifikasi perilaku, memahami \& memberi motivasi, memahami proses persepsi dan pembentukan komunikasi yang efektif.

Menurut Mudrajad Kuncoro, model kepemimpinan strategis mencakup dua aksi;

1. Membimbing organisasi dalam menghadapi perubahan yang terus menerus, dan

2. Menawarkan keahlian manajemen untuk mengatasi perubahan yang terus menerus.

Inti dari kedua aksi itu, bermuara pada perumusan strategic intent (artikulasi atau karakteristik yang ingin dicapai organisasi), pengembangkan organisasi, serta pembentukan kultur organisasi.

Pelaksanaan kepemimpinan strategik yang efektif menurut Mudrajad Kuncoro, meliputi :

1. Arah Strategik berarti pengembangan visi jangka panjang, yang seorang pemimpin mesti mampu untuk membantu pencapaian maksud strategik tersebut,

2. Kompetensi Inti, maksudnya sumber daya dan kapabilitas yang menjadi sumber keunggulan kompetitif organisasi, sehingga seorang pemimpin strategik harus membuktikan bahwa kompetensi organisasi ditekankan dalam usaha penerapan strategi,

3. Modal Manusia, menunjuk kepada pengetahuan dan ketrampilan keseluruhan anggota dan pengurus yang menjadi sumber daya kapital utama bagi perjalanan organisasi,

4. Budaya Organisasi, meliputi kumpulan yang kompleks mengenai ideologi, simbol, dan nilai inti yang berlaku dan mempengaruhi cara menjalankan organisasi, dan seorang pemimpin bertugas untuk mempertajam budaya organisasi agar lebih efektif,

5. Praktek Etika, penting dalam proses penerapan strategi karena organisasi yang etis mendorong dan memungkinkan individu pada seluruh tingkat organisasi untuk melakukan penilaian etika, dan terakhir

6. Kontrol Organisasi menyediakan parameter strategi dan tindakan koreksi mana yang akan diterapkan.

Menurut Sedarmayanti, salah satu peran kunci kepemimpinan organisasi yang baik yaitu membangun organisasi dengan cara mendidik dan mengembangkan calon pemimpin baru. Masing-masing calon nantinya akan menjadi manajer global, agen perubahan, penyusun strategi, motivator, pembuat keputusan stratejik, innovator dan kolaborator jika kegiatan tersebut tetap bertahan dan berkembang. Hal ini akan tampak bila melihat kompetisi kunci yang perlu dimiliki dan dikembangkan manajer masa depan. Kebutuhan yang diharapkan organisasi akan dipenuhi oleh manajer. Organisasi mengindentifikasi kompetensi sesuai yang perlu dilakukan manajer

Kompleksitas dan dinamika perkembangan lingkungan stratejik, pada tataran nasional ditandai oleh permasalahan dan tantangan yang multi dimensional, di bidang sosial, ekonomi, politik, kelembagaan, serta pertahanan dan keamanan, yang di awal Abad 21 ini ditandai antara lain oleh lemahnya struktur dan daya saing perekonomian, penegakkan hukum, pelaksanaan otonomi dan desentralisasi, besarnya hutang luar negeri, tingkat kemiskinan dan pengangguran, tuntutan demokratisasi, dan ancaman desintegrasi. Pada tataran internasional, terdapat perkiraan bahwa perkembangan lingkungan global ditandai situasi, kondisi, tantangan dan tuntutan, yang makin kompleks, selalu berubah, penuh ketidakpastian, dan bahkan sering tidak ramah.

Perkembangan lingkungan stratejik tersebut menuntut pemimpin dan kepemimpinan yang solid, mampu mengantisipasi perkembangan ke depan, membangun visi, misi, dan strategi serta mengembangkan langkah-langkah kebijakan, sistem kelembagaan dan

Kompetensi
Kepemimpinan

Karyawan

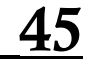

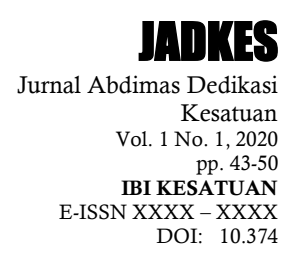


Kompetensi

Akuntansi Siswa SMK

\section{$\underline{46}$}

\section{JADKES}

Jurnal Abdimas Dedikasi Kesatuan

Vol. 1 No. 1,2020

pp. $43-50$

IBI KESATUAN

E-ISSN XXXX - XXXX

DOI: manajemen perusahaan yang relevan dengan kompleksitas perkembangan, permasalahan, dan tantangan yang dihadapi, baik pada tataran nasional maupun internasional. Organisasi agar berhasil harus mampu dan mau melakukan perubahan sesuai dengan perubahan kondisi lingkungan stratejiknya (internal maupun eksternal).

Berdasarkan penjelasan diatas, khususnya hal yang berkaitan dengan strategi kepemimpinan dan untuk keberhasilan perusahaan, maka setiap perusahaan hanya akan dapat bertahan, jika dipimpin oleh seorang pemimpin yang memiliki strategi dalam kepemimpinannya. Pelatihan strategi kepemimpinan ini sangat diperlukan bagi para calon pemimpin masa depan, yang dapat dilaksanakan melalui kerjasama dengan Perguruan Tinggi dalam berbagi ilmu pengetahuan dan pengalaman bagi perkembangan kepemimpinan dalam suatu organisasi agar dapat lebih berkembang. Untuk maksud tersebut, LPPM STIE Kesatuan bekerjasama dengan Bank Perkreditan Mitra Kota Bogor menyelenggarakan program pelatihan dengan tema strategi kepemimpinan untuk membantu calon pemimpin masa depan dalam mengembangkan BPR Mitra se Kota Bogor.

Berdasarkan permasalahan diatas, tujuan penyelenggaraan pelatihan strategi kepemimpinan bagi calon pemimpin BPR Mitra se Kota Bogor adalah :

1. Memberikan pengetahuan dan pemahaman mengenai pentingnya strategi kepemimpinan bagi calon pemimpin masa depan di lingkungan BPR Mitra Bogor sebagai upaya untuk mengembangkan usaha BPR Mitra Bogor.

2. Meningkatkan pemahaman mengenai karakteristik kepemimpinan da- lam mendukung kelancaran kegiatan di lingkungan BPR Mitra.

3. Memberikan pemahaman mengenai perlunya strategi kepemimpinan dalam mendukung kelangsungan jalannya usaha agar BPR Mitra dapat terus menjalankan dan mengembangkan usahanya.

\section{PELAKSANAAN KEGIATAN \\ Waktu Pelaksanaan}

Kegiatan Pengabdian kepada Masyarakat ini dilaksanakan pada tanggal 12 - 13 Juli 2019 yang difasilitasi oleh STIE Kesatuan dan BPR Mitra Kota Bogor. Selanjutnya STIE Kesatuan dan BPR Mitra Kota Bogor menentukan peserta pelatihan yang terdiri dari calon pemimpin dari BPR Mitra di wilayah Kota Bogor. Pelatihan dengan tema : strategik kepemimpinan ini diselenggarakan selama 2 hari, yaitu pada tanggal $12-13$ Juli 2019.

\section{Kerangka Pemecaham Masalah}

Permasalahan yang diangkat dalam kegiatan pengabdian pada masyarakat adalah meningkatkan pengetahuan, pemahaman mengenai kepemimpinan dan strategik kepemimpinan yang penting untuk dipahami oleh seorang pemimpin dalam perusahaan dalam mendukung aktivitasnya sebagai pemimpin perusahaan. Kerangka pemecahan masalah dimaksud dilakukan dengan menerapkan langkah kerja dalam pengabdian pada masyarakat sebagai berikut :

a Menetapkan jumlah peserta pelatihan yakni sebanyak 20 orang dari calon pemimpin BPR Mitra di Kota Bogor.

b. Seluruh peserta dikumpulkan dalam suatu ruangan yang memadai di lingkungan STIE Kesatuan yang dilengkapi dengan sarana dan prasarana yang memadai.

c. Memberikan materi pelatihan yang meliputi :

- Materi 1 : Memberikan pengetahuan dan pemahaman tentang kepemimpinan, guna mengenal karakteristik dan tujuan dari kepemimpinan bagi pengembangan usaha BPR Mitra.

- Materi 2 : pemahaman mengenai strategik kepemimpinan yang dapat digunakan dan dipraktekkan dalam memimpin perusahaan BPR Mitra.

Adapun kerangka berpikir untuk pemecahan masalah dapat dijelaskan dalam bentuk matrik sebagai berikut : 
Tabel 1 Masalah dan Solusi Yang Ditawarkan

\begin{tabular}{|l|l|}
\hline \multicolumn{1}{|c|}{ Masalah } & \multicolumn{1}{c|}{ Upaya Pemecahan Masalah } \\
\hline $\begin{array}{l}\text { Bagaimana memberikan penge- } \\
\text { tahuan dan pemahaman } \\
\text { kepemimpinan bagi calon pemimpin } \\
\begin{array}{l}\text { BPR Mitra dalam menjalankan dan } \\
\text { mengembangkan usahanya. }\end{array}\end{array}$ & $\begin{array}{l}\text { Dilakukan dengan cara memberikan ceramah, } \\
\text { tanya jawab, diskusi dan contoh kasus yang } \\
\text { dapat dilaksa- naan oleh para calon pemimpin } \\
\text { di lingkungan BPR Mitra Bogor. }\end{array}$ \\
\hline $\begin{array}{l}\text { Bagaimana memberikan } \\
\text { pemahaman mengenai strategik } \\
\text { kepemimpinan. }\end{array}$ & $\begin{array}{l}\text { Dilakukan dengan cara memberikan ceramah, } \\
\text { tanya jawab, diskusi dan menjelaskan contoh } \\
\text { kasus serta memberikan pencerahan lewat } \\
\text { contoh-contoh yang saat ini sudah } \\
\text { dipraktekkan terhadap pemahaman strategik } \\
\text { kepemimpinan. }\end{array}$ \\
\hline
\end{tabular}

\section{Khalayak Sasaran Antara Yang Strategis}

Sasaran kegiatan ini adalah calon pemimpin di lingkungan BPR Mitra se Kota Bogor. Pertimbangan pemilihan dan penetapan sasaran pelatihan ini adalah untuk meningkatkan kemampuan calon pemimpin di lingkungan BPR Mitra dalam mengelola dan mengembangkan usahanya, khsususnya fokus pada implementasi kepemimpinan dan strategik kepemimpinan, sehingga dapat meningkatkan kinerja calon pemimpin BPR Mitra. Selanjutnya STIE Kesatuan sebagai Perguruan Tinggi yang memiliki fungsi dalam menjalankan Pengabdian Kepada Masyarakat melalui bidang keilmuan akuntansi dan manajemen, guna dapat membantu dan meningkatkan kemampuan para calon pemimpin di lingkungan BPR Mitra dalam mengelola dan mengembangkan bidang usahanya

\section{Keterikatan}

Kegiatan pengabdian pada masyarakat ini terselenggara dengan adanya kerjasama antara BPR Mitra dengan STIE Kesatuan yang secara teknis dilakukan oleh Lembaga Penelitian dan Pengbdian kepada Masyarakat (LPPM) yang didukung oleh sumber daya manusia yang bermutu dan profesional sesuai dengan bidang keahliannya. Hal-hal yang berkaitan dengan sumber daya manusia serta sarana dan prasarana LPPM STIE Kesatuan dapat dijelaskan sebagai berikut:

1. Memiliki dosen yang profesional dan berpengalaman dalam menghasilkan berbagai jenis karya tulis ilmiah yang bermutu sesuai dengan perkembangan ilmu dan pengetahuan.

2. Memiliki dosen yang profesional dan berpengalaman dalam pelaksanaan kegiatan penataran, pelatihan, seminar dan workshop.

Adapun potensi yang dimiliki oleh calon pemimpin BPR Mitra adalah memiliki keinginan yang kuat untuk meningkatkan kemampuan dalam membangun dan mengembangkan usaha BPR Mitra. Dengan berkembangnya usaha BPR Mitra di Kota Bogor maka diharapkan akan meningkatkan perkembangan ekonomi di Kota Bogor.

\section{Metode Kegiatan}

Metode kegiatan yang dijalankan berupa pemberian pelatihan kepada calon pemimpin di lingkungan BPR Mitra se Kota Bogor. Setelah diberikan pelatihan, para calon pemimpin BPR Mitra diharapkan dapat mengimplementasikan pengetahuan dan pemahaman yang telah diperoleh untuk membantu para calon pemimpin BPR Mitra dalam mengelola dan mengembangkan usaha yang dijalankannya, khususnya fokus pada pengembangan BPR Mitra. Berikut disajikan tahapan pelatihan yang dilakukan:

Tahap Persiapan

Pada tahap persiapan hal yang dilakukan meliputi : Pembicaraan dengan Pimpinan BPR Mitra dan STIE Kesatuan Bogor, Penentuan target peserta pelatihan, Pemantapan dan penentuan lokasi dan sasaran dan Penyusunan bahan/materi pelatihan : makalah dan modul untuk kegiatan pelatihan strategik kepemimpinan bagi calon pemimpin di lingkungan BPR Mitra.
Kompetensi

Kepemimpinan

Karyawan

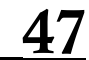

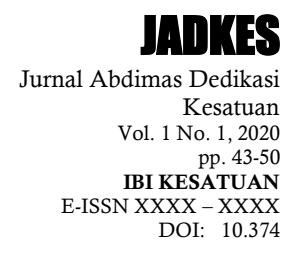


Kompetensi

Akuntansi Siswa $S M K$

48

\section{JADKES}

Jurnal Abdimas Dedikasi

Kesatuan

Vol. 1 No. 1, 2020

pp. $43-50$

IBI KESATUAN

E-ISSN XXXX - XXXX

DOI:
Tahap Pelaksanaan Pelatihan

Tahap pelaksanaan merupakan tahapan inti penyelenggaraan kegiatan pelatihan strategik kepemimpinan bagi para calon pemimpin di lingkungan BPR Mitra Bogor. Pada tahap ini kegiatan yang dilakukan sebanyak 3 sessi, yakni :

a. Sessi pertama. Pada sessi ini pembicara memberikan pengetahuan dan pemahaman para calon pemimpin di BPR Mitra mengenai pentingnya kepemimpinan, apa itu kepemimpinan, peran kepemimpinan dan bagaimana seorang pemimpin dapat bekerja dan menggerakkan bawahannya dalam mencapai tujuan perusahaan.

b. Sessi kedua. Pada sessi ini pembicara

c. menjelaskan berbagai hal mengenai pemahaman mengenai strategik kepemimpinan dalam menjalankan suatu perusahaan.

d. Sessi ketiga. Pada sessi ini membahas praktek-praktek kepemimpinan dalam suatu perusahaan.

Metode Pelatihan

Metode kegiatan pelatihan dapat dijelaskan sebagai berikut :

a. Metode Ceramah

Metode ini digunakan untuk memberikan penjelasan tentang kepemimpinan dan strategik kepemimpinan, tujuan, manfaat, pentingnya strategik kepemimpinan beserta contoh penerapannya.

b. Metode Tanya Jawab

Metode ini bagi peserta untuk mengetahui hal-hal yang belum dipahami mengenai strategik kepemimpinan, tujuan, manfaat, pentingnya memahami strategik kepemimpinan beserta contoh penerapannya. Metode ini berupaya untuk mengeksplorasi materi yang disajikan agar dapat dipahami dengan baik oleh para calon pemimpin di lingkungan BPR Mitra.

\section{HASIL DAN PEMBAHASAN}

\section{Hasil Pelaksanaan Kegiatan}

Program kegiatan pengabdian kepada masyarakat ini dilaksanakan bagi calon pemimpin di lingkungan BPR Mitra se Kota Bogor yang dilaksanakan pada tanggal 12 13 Juli 2019. Kegiatan pelatihan ini dilaksanakan dengan metode :

1. Metode Ceramah. Metode ini digunakan untuk memberikan penjelasan tentang kepemimpinan dan strategi kepemimpinan, tujuan, manfaat, pentingnya dan keahlian yang harus dimiliki oleh seorang pemimpin beserta contoh penerapannya.

2. Metode Tanya Jawab. Metode ini bertujuan untuk mengetahui hal-hal yang belum dipahami mengenai kepemimpinan dan strategi kepemimpinan, tujuan, manfaat, pentingnya dan tekhnik strategi kepemimpinan yang akan diterapkan beserta contoh penerapannya. Metode ini berupaya untuk mengeksplorasi antara materi yang disajikan dengan kondisi yang ada di lingkungan BPR Mitra Kota Bogor, sehingga materi yang disampaikan oleh narasumber dapat dipahami dengan baik.

\section{Evaluasi Hasil Kegiatan}

Evaluasi proses dan hasil pelatihan ini dilakukan melalui tanya jawab dan evaluasi dilakukan oleh BPR Mitra Bogor. Indikator keberhasilan dalam pelaksanaan pelatihan kepemimpinan dan strategi kepemimpinan ini, terdiri dari 2 (dua) metode, yakni :

a. Evaluasi selama proses pelatihan. Selama proses pelatihan dilakukan, tim Lembaga Penelitian dan Pengabdian Kepada Masyarakat (LPPM) STIE Kesatuan melakukan penilaian terhadap keterlibatan dan kemampuan peserta pada setiap tahap pelatihan. Peserta cukup antusias dalam mengikuti pelatihan tersebut, terbukti dengan banyaknya pertanyaan yang diajukan berkaitan dengan materi yang disampaikan. Berdasarkan kondisi tersebut, pelatihan ini memang sangat dibutuhkan bagi pengembangan kemampuan para calon pemimpin di lingkungan BPR Mitra di Kota Bogor.

b. Evaluasi pasca pelatihan. Setelah pelatihan diselenggarakan, diharapkan dapat 
meningkatkan kemampuan peserta dalam menjalankan strategi kepemimpinan bagi calon pemimpin di BPR Mitra Kota Bogor. Diharapkan setelah pelaksanaan pelatihan, komunikasi dengan pimpinan BPR Mitra Bogor tetap terbina. Apabila calon pemimpin BPR Mitra mengalami kesulitan STIE Kesatuan siap membantu dan memberi bimbingan lebih lanjut. Diharapkan akan tetap terbina hubungan yang baik antara STIE Kesatuan dengan BPR Mitra Bogor.

\section{Pembahasan}

Kegiatan program Pengabdian kepada Masyarakat yang diselenggarakan oleh Lembaga Penelitian dan Pengabdian pada Masyarakat (LPPM) STIE Kesatuan ini telah terselenggara dengan baik dan lancar. Secara umum para peserta memberikan respon positif atas pelaksanaan kegiatan ini. Para peserta mengharapkan kegiatan ini dapat diselenggarakan secara rutin dengan topik yang lebih beragam, sehingga dapat memberikan pemahaman mengenai pengelolaan perusahaan dengan baik yang dampaknya akan memperluas kegiatan usaha BPR Mitra di Kota Bogor. Dengan demikian para peserta dapat bersaing secara baik dalam kompetisi bisnis yang sedang berjalan. Hal lain yang menjadi perhatian peserta adalah bagaimana merespon kondisi persaingan dalam era Masyarakat Ekonomi ASEAN (MEA) yang akan segera berlangsung.

Respon positif juga diberikan oleh pimpinan BPR Mitra Kota Bogor yang telah memfasilitasi kegiatan pelatihan strategik kepemimpinan yang perlu dipahami oleh para calon pemimpin di lingkungan BPR Mitra Kota Bogor. Dengan terselenggaranya kegiatan pelatihan strategik kepemimpinan bagi calon pemimpin BPR Mitra se Kota Bogor diharapkan para peserta dapat tumbuh dan mengembangkan BPR Mitra dengan lebih baik lagi sehingga dapat membantu para calon pemimpin dalam mencapai tujuan perusahaan. Sehingga pada akhirnya nanti kondisi tersebut akan meningkatkan perumbuhan perekonomian di Kota Bogor

\section{PENUTUP}

Pelaksanaan kegiatan Pengabdian kepada Masyarakat berupa pelatihan strategik kepemimpinan bagi calon pemimpin di lingkungan BPR Mitra se Kota Bogor menunjukkan hasil yang baik. Indikator kepuasan atas pelaksanaan pelatihan tersebut antara lain :

1. Respon positif yang ditunjukkan oleh peserta selama kegiatan berlangsung. Respon tersebut berupa banyaknya pertanyaan dan tanggapan yang diberikan secara langsung, khususnya mengenai implementasi materi atas usaha yang sedang berjalan. Pembicara memberikan respon dan jawaban yang cukup memuaskan sehingga peserta memperoleh pemahaman yang lebih baik dibandingkan sebelum mengikuti pelatihan ini.

2. Kesesuaian antara materi dengan kebutuhan pengelolaan usaha, khususnya mengenai strategik kepemimpinan bagi calon pemimpin di lingkungan BPR Mitra untuk dapat lebih bersaing dalam mengem- bangkan usahanya.

3. Peserta memahami pentingnya materi yang disajikan karena berkaitan dengan usaha yang sedang dikelola BPR Mitra, sehingga banyak pertanyaan yang diajukan terkait dengan materi yang disampaikan oleh narasumber.

4. Kegiatan pengabdian kepada masyarakat ini dapat dijadikan sharing pengetahuan konseptual hingga implementasi bagi narasumber dan peserta. Sehingga menjadi sarana transfer knowledge yang dilakukan antara narasumber yang berlatar belakang akademisi dan praktisi dengan pelaku usaha di BPR Mitra Kota Bogor.

Rekomendasi yang dapat diberikan sehubungan dengan penyelenggaraan kegiatan pelatihan strategik kepemimpinan dapat dijelaskan sebagai berikut :

a. Peserta yang mengikuti pelatihan diharapkan dapat meningkatkan pengetahuan serta pemahaman mengenai strategik kepemimpinan dalam upaya pencapaian tujuan perusahaan dalam mempertahankan keberlangsungan usaha yang sedang dikelola.

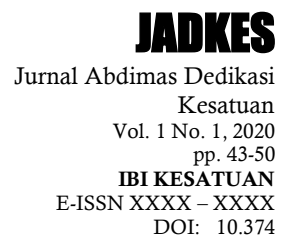

Kompetensi

Kepemimpinan

Karyawan

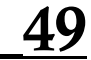


Kompetensi Akuntansi Siswa $S M K$

\section{$\underline{50}$}

\section{IATKES}

Jurnal Abdimas Dedikasi Kesatuan Vol. 1 No. 1,2020 pp. 43-50 pp. 43-50 E-ISSN XXXX - XXXX DOI: b. Pelatihan yang diselenggarakan bagi peserta sebaiknya dilaksanakan secara rutin dan terprogram dengan materi yang lebih bervariatif, sehingga dapat membuka wawasan peserta dalam menjalankan tugasnya.

c. BPR Mitra dapat bekerjasama dengan institusi pendidikan untuk menyusun kurikulum pelatihan sehingga proses pembinaan sumber daya manusia para calon pimpinan di lingkungan BPR Mitra Kota Bogor dapat ditingkatkan. Dampak yang diharapkan adalah meningkatkan softskill dan hardskill para calon pemimpin di BPR Mitra Kota Bogor dalam mengelola usahanya dengan lebih baik.

\section{DAFTAR PUSTAKA}

Binangkitsari, L., 2018. The Influence of Brand Equity Elements on Purchase Decision and Its Imlication on Customer Loyalty.

Iriyadi, I., 2019. Prevention of Earnings Management through Audit Committee and Audit Quality in the Award-Winning and Non-Winning Companies. Journal of Accounting Research, Organization and Economics, 2(2), pp.155-169.

Iriyadi, I., Maulana, M.A. and Nurjanah, Y., 2018, December. Financial Reporting for Micro Small and Medium Enterprises Towards Industrial Revolution Era 4.0. In International Conference On Accounting And Management Science 2018 (pp. 32-38).

Kembauw, E., Munawar, A., Purwanto, M.R., Budiasih, Y. and Utami, Y., 2020. Strategies of Financial Management Quality Control in Business. Manfacturers' Capital Structure.

Kadir, Abdul Rahman. 2001. Makalah : Karakter Kepemimpinan Nasional. Wursanto. Ignatius. 2009. Dasar-dasar Ilmu Organisasi. Edisi dua. Yogyakarta: Andi.

Kartono, Kartini. 2009. Pemimpin dan Kepemimpinan. Rajawali Press.

Mudrajat Kuncoro. 2005. Strategi Bagaimana Meraih Keunggulan Kompetiti Erlangga. Jakarta.

Munawar, A., The Effect of Leverage, Dividend Policy, Effectiveness, Efficiency, and Firm Size on Firm Value in Plantation Companies Listed on IDX.

Munawar, A., Syarif, R. and Morita, M., 2019. Persepsi Mahasiswa Atas Galeri Investasi Perguruan Tinggi dan Pengaruhnya Terhadap Minat Berinvestasi. JAS-PT (Jurnal Analisis Sistem Pendidikan Tinggi Indonesia), 3(2), pp.89-96.

Paomey, Jifvy Magdalena Dina, and Bambang Pamungkas. "Improving Quality of Information On Local Financial Statements and Its Utilization for Capital Expenditure Budgeting (Case Study at The Provincial Government of East Nusa Tenggara)." In 3rd Asia-Pacific Research in Social Sciences and Humanities Universitas Indonesia Conference (APRISH 2018). Atlantis Press, 2019.

Pamungkas, B., Ibtida, R. and Avrian, C., 2018. Factors influencing audit opinion of the Indonesian municipal governments' financial statements. Cogent Business \& Management, 5(1), p.1540256.

Pratiwi, Y. and Pamungkas, B., 2014. Analisis Pengakuan Pendapatan, Belanja, dan Pembiayaan Daerah Pada Pemerintah Daerah Kota Bogor. Jurnal Ilmiah Akuntansi Kesatuan, 2(1), pp.059-072.

Purba, J.H.V. and Septian, M.R., 2019. Analysis of Short Term Financial Performance: A Case Study of an Energy Service Provider. Journal of Accounting Research, Organization and Economics, 2(2), pp.113-122.

Purba, J.H.V., 2001. Keragaan Kelapa Sawit Indonesia Ditinjau dari Jenis Pengusahaan dan Wilayah Produksi (Doctoral dissertation, Doctoral dissertation, Tesis Magister Sains. Program Pascasarjana, Institut Pertanian Bogor, Bogor).

Sedamayanti. 2016. Membangun dan mengembangkan Kepemimpinan Serta Meningkatkan Kinerja Untuk Meraih Keberhasilan. Cetakan kedua. Refika. Jakarta.

Sedarmayanti. 2015. Reformasi Administrasi Publik, Reformasi Birokrasi, dan Kepemimpinan Masa Depan 